\title{
Participation and Coordination between Companies and the Cirebon City Government in Poverty Alleviation through Corporate Social Responsibility Programs
}

\author{
Moh.Taufik Hidayat ${ }^{1}$, Moh.Sutarjo ${ }^{2}$ \\ 1,2Universitas Swadaya Gunung Jati Cirebon, Indonesia \\ Email:hidayatmtaufik26@gmail.com
}

\begin{abstract}
One of the crucial problems faced in the city of Cirebon is the poverty rate, which is quite high and continues to increase from year to year. The Corporate Social Responsibility (CSR) Program or Corporate Social and Environmental Responsibility (TJSL), according to Cirebon Mayor Regulation Number 42 of 2015, is one of the poverty reduction programs in Cirebon City. This study aimed to determine the participation and coordination of companies with the Cirebon City Government in poverty reduction through the CSR Program. The research method used qualitative methods with collection in literature studies, documentation studies, interviews, and observations. The results of the study were the participation of companies to coordinate with the Cirebon City Government. Poverty reduction through the CSR program has not been optimal because the majority of companies implement CSR programs directly to target groups without coordinating with the Cirebon City Government. The factors that influence the company's participation in coordinating with the Cirebon City Government in poverty reduction through the CSR Program are the sub-optimal leadership of the Mayor of Cirebon, the lack of communication between the Cirebon City Government and company leaders, and the inadequate education of company leaders in the form of awareness, knowledge, and understanding of coordination mechanism in the CSR Program.
\end{abstract}

Keywords: Participation, Coordination, Corporate Social Responsibility, Company, City Government.

\section{A. INTRODUCTION}

In principle, the company was founded to generate maximum profit (Ardimas \& Wardoyo, 2015; Anita \& Yulianto, 2016). The company's main business is production activities that produce products in the form of goods and offering activities in the form of service products (Daniel \& Bryson, 2002). The company's outline is to get the maximum economic benefit and prevent losses as much as possible or minimize losses as much as possible (Lindahl, 2014).

On the one hand, it must be admitted that the Company is one of the pillars and drivers of the national economy (Tubagus, 2020). The company's role in enhancing national economic growth is part of its positive contribution. Creation of employment, products of goods and services generated from the Company's business, and payment of taxes that provide income for the state are the most beneficial contributions (Nurbaety et al., 2015).

Companies that are established in an area and are in the midst of a society that benefits from the business results should now change this way of thinking. 
According to Wjaya (2012), the company is no longer only a selfish entity or exclusivity from the community, but as a legal entity that is obliged to adapt sociocultural to the environment in which it is held accountable a legal subject. in general (Oktariani \& Mimba, 2014).

As a legal entity, the company has a Corporate Social Responsibility (CSR) (Kamil \& Herusetya, 2012; Subiantoro \& Mildawati, 2015). In practice, so far, there are still several companies that carry out corporate social responsibility programs or CSR is only voluntary without a sustainable commitment (Anatan, 2009).

One of the crucial problems faced by the City of Cirebon is the high poverty rate. Based on data from the Social Service, Women Empowerment, and Child Protection of Cirebon City, in 2019, there were 28,393 poor households (KK). The number of low-income families is spread across five sub-districts, namely Pekalipan District (3,317 KK), the Kejaksan District (3,624 KK), Kesambi District (5,499 KK), and the Harjamukti District $(9,370 \mathrm{KK})$. The number of poor households in 2019 increased compared to 2015, which amounted to 27,257 households. Thus, during the five years (2015-2019), the number of low-income families in Cirebon City increased by 1,136 households $(4.2 \%)$ or an average increase of 227 families $(0.8 \%)$ per year. In the city of Cirebon during the Covid-19 pandemic, it is certain that it has increased sharply because of layoffs or their business has experienced a setback, even bankruptcy.

In the context of poverty reduction, the Cirebon City Government has enacted Cirebon Mayor Regulation Number 42 of 2015 concerning the Coordination Mechanism for Poverty Reduction in Cirebon City. According to the Mayor's Regulation, poverty reduction is carried out in four program groups, namely:

1. Family-Based Integrated Social Assistance Program Group.

2. Community Empowerment Program Group.

3. Small and Micro Economic Business Empowerment Program Group.

4. Group of Corporate Social Responsibility (CSR) Programs.

The CSR or Corporate Social and Environmental Responsibility (TJSL) Program in Cirebon City is held based on Cirebon City Regional Regulation Number 14 of 2012 concerning the Implementation of Corporate TJSL in Cirebon City, and Cirebon Mayor Regulation Number 38 of 2016 concerning Guidelines for Implementation of Cirebon City Regional Regulation Number 142012 concerning the Implementation of Corporate Social Responsibility in Cirebon City.

The CSR program is a very strategic poverty reduction program. This is because the potential for CSR funds in Cirebon City is relatively large, while the Cirebon City APBD is limited to finance various poverty reduction programs. For example, the Cirebon City APBD in 2019 is only IDR 1.67 trillion, while the potential TJSL funds in Cirebon City reach IDR 1 trillion per year. Therefore, companies must participate through the CSR Program to assist the Cirebon City Government in poverty alleviation.

In the Cirebon Mayor Regulation Number 42 of 2015, it is stated that companies must coordinate with the Cirebon City Government in implementing the 
CSR program for poverty reduction. In fact, most companies do not coordinate with the Cirebon City Government but directly distribute social assistance or its programs to target groups in the context of poverty reduction. This causes social assistance distribution, and these programs are often not on target, overlapping, and not following the set priority agenda by the Cirebon City Government.

This study aimed to analyze how the participation and coordination of companies with the Cirebon City Government in poverty reduction through the Corporate Social Responsibility (CSR) Program.

\section{B. LITERATURE REVIEW}

\section{Participation}

Development is a process of continuous and continuous renewal from a certain condition to a condition that is considered better. In developing countries, these reform efforts are generally undertaken with government and with planned efforts. Development, which includes all political, economic, and socio-cultural life, will only be successful if it is an activity that involves the participation of all the people in a country (Tjokroamidjojo, 1993).

Etymological participation means participation, participation, involvement, contribution, participation, cooperation, cooperation. Participation means playing/participating, following, embracing, engaging, engaging (Endarmoko, 2006). Meanwhile, by definition, participation is the mental / thought and emotional / feeling involvement of a person in a group situation that encourages him to contribute to the group to achieve goals. And share responsibility for the business concerned (Sastropoetro, 1990).

Participation is divided into several types. According to Sastropoetro (1990), the types of participation are thought participation, energy participation, mind and energy participation, expertise participation, goods participation, and money participation. Participation does not arise automatically but is determined by several determinants. Tjokroamidjojo (1993) suggests three determinants that influence participation: leadership, communication, and education.

\section{Coordination}

According to Mooney and Reily (Handayaningrat, 2000), the definition of coordination is the achievement of regular group efforts and unity of action in achieving common goals. Meanwhile, McFarland defines coordination as a process in which leaders develop regular group business patterns among their subordinates and ensure unity of action in achieving common goals (Handayaningrat, 2000). According to the Administrative Encyclopedia, coordination is an understanding contained in non-chaos, bickering, twinning, or work vacancies resulting from connecting, integrating, and harmonizing people, work units, and their work in collaboration, which is directed to the achievement of certain goals (Westra et al., 1990). 
The characteristics of coordination, according to Mc. Farland, namely: the responsibility for coordination lies with the leadership, the existence of the process, the regular arrangement of group efforts, the concept of the unity of action, and the objectives of coordination are common goals (Handayaningrat, 2000).

Sugandha (1991) suggests several principles that need to be applied in creating coordination, namely:

a. There are agreements and unity of understanding regarding the goals that must be achieved as the direction of joint activities.

b. There is an agreement regarding the activities or actions that each party must carry out, including targets and schedules.

c. There is obedience or loyalty from each party to their respective duties and schedules that have been set.

d. There is an exchange of information from all cooperating parties regarding the activities and results at a certain time, including the problems each one faces.

e. There is a coordinator who can lead and mobilize and monitor this collaboration and lead joint problem-solving problems.

f. There is information from various parties flowing to the coordinator so that the coordinator can monitor all implementation of the collaboration and understand the problems faced by all parties.

g. There is mutual respect for each party's functional authority, thus creating a spirit to help each other.

If it is related to the determinant factors that affect participation (Tjokroamidjojo, 1993), the 1, 2, 4, and 6 coordination principles are related to the communication factor, the 5th and 7 th coordination principles are related to the leadership factor, while the 3rd coordination principle is related to the communication factor and educational factor. Thus, coordination has a lot to do with communication because effective communication is a prerequisite for effective coordination.

Coordination is a term that is easy to pronounce but difficult to implement because of many problems in its implementation or implementation. Stoner (1986) suggests problems to achieve effective coordination, namely: differences in orientation towards certain goals, differences in time orientation, differences in interpersonal orientation, and differences in structural formality.

To achieve effective coordination, Galbraith (Stoner, 1986) suggests three approaches, namely:

a. Basic management techniques, which include managerial hierarchies, rules and procedures, and plans and goals.

b. Increase coordination potential, including vertical information systems and lateral relations.

c. Reducing the need for coordination, including "spare" resources and independent units. 


\section{Corporate Social Responsibility (CSR)}

The government's main task is to provide public services in various fields, one of which is in the social field called social services. Social services are a form of social policy. The state establishes social policies, but the state is not the only actor that organizes these social services because of social services. It can also be done by the business world (companies), the community, and other parties. However, because social services are a form of social policy established by the state, social services cannot and should not be left to the public and private parties. As an institution with public legitimacy that is elected and financed by the people, the state (government) has an obligation to fulfill, protect, and respect its citizens' basic, economic and cultural rights (Suharto, 2013).

According to the International Convention, the state's mandate to provide social services is stronger than that of the public or business world. Therefore, the mandate of the state in social services is "mandatory," while the mandate of the community and the business community (companies) in social services is "responsible" (Suharto, 2013). If the business world (companies) performs social services, it is called social responsibility, not the social obligation, because the state (government) has a social obligation.

Social responsibility is based on the fact that no organization can grow and develop without the support and trust of its environment. Social responsibility can be carried out in various forms, namely the use of labor, the use of the surrounding community as a supplier of raw materials, involvement in social activities, provision of public facilities and infrastructure, and playing an active role in the development of the surrounding community (Siagian, 2000).

Corporate social responsibility in social services is carried out in the form of CSR. According to The World Business Council for Sustainable Development (WBCSD), CSR is the business world's commitment to continue to act ethically, operate legally, and contribute to economic improvement and quality improvement. Lives of employees and their families and improving the quality of the local community and society at large (Wibisono 2007). The company is a central point in sustainable development. This is because the company's activities have an impact on the financial aspects and organizational culture of the company and create social and environmental impacts from the company's activities, both in the short and long term (Aras \& Crowther, 2007).

Concerning sustainable development, Elkington (Wibisono, 2007) developed a triple bottom line concept in CSR. If a company wants to be sustainable, it must pay attention to 3Ps (Profit, People, Planet). Therefore, the company, in addition to pursuing profit, must also pay attention to and be involved in fulfilling the community's welfare (people) and contribute actively to preserving the environment (planet).

According to Caroll (1991), corporate responsibility in CSR consists of four types, namely: 
a. Economic responsibility. The keyword is profitable. Companies have shareholders who want a fair return on their investment. Besides, companies have employees who want jobs that are safe and are paid fairly. The company also has consumers who want a good quality product at a fair price, etc. This is why business stands in society, so the company's first responsibility is to become a functioning economic unit and survive in its business. This first layer of CSR is the basis for all subsequent responsibilities, which rests on this solid foundation.

b. Legal responsibility. The keyword is to obey the law. Corporate liability requires that the company's business must comply with the law and "play by the rules of the game." Law is understood as a codified view of society's morals, so complying with these standards is a prerequisite for further social responsibility reasons.

c. Ethical responsibility. The keyword is to be ethical. This responsibility obliges companies to do what is right, fair, and fair, even when they are not required to do so by the legal framework. This ethical responsibility creates general expectations that society expected, where these expectations are above the expectations of economic and legal responsibility.

d. Philanthropic responsibility. The keyword is to be a good citizen. In addition to having to make a profit, obey the law and behave ethically, companies are also required to contribute directly to the community to improve the quality of life for all. In this case, the owner and employees who work in the company have a dual responsibility, namely to the company and the public (society), known as nonfiduciary responsibility.

CSR, which is widely known by the community, is CSR in philanthropic responsibility, which contains social responsibility to society (people or society) and responsibility to the environment (planet).

\section{METHOD}

This study's research method is a qualitative method that produces descriptive data in the form of written or spoken words from people and observed behavior (Moleong, 2009). The qualitative research strategy that the author uses is a case study. The researcher carefully investigates a program, event, activity, process, or group of individuals limited by time and events (Creswell, 2014). Case studies are research whose research subjects can be individuals, groups, institutions, or communities to provide a detailed description of the background, the characteristics and characteristics of the case, which then from the characteristics above will make a thing, which is general in nature (Nazir, (2011). Data collection is carried out by literature/documentation and field studies in interviews and observations. Data analysis is carried out using descriptive analysis, which includes data reduction, data display, verification, and conclusion (Moleong, 2009) While checking the validity of the data is done by using triangulation techniques by using something 
other than the data for checking purposes or as a comparison to the data (Moleong, 2009).

\section{RESULT AND DISCUSSION}

Coordination in the Corporate Social Responsibility (CSR) Program in Cirebondi is regulated in the TJSL Regional Regulation, namely:

1. One of the principles of implementing TJSL in Cirebon City is the principle of integration. Each TJSL implementation is carried out in an integrated manner by taking into account the city's interests, other sectors, and the local community.

2. One of the objectives of the TJSL Perda is the fulfillment of coordinated TJSL implementation following the prevailing laws and regulations.

3. In the TJSL Program, the company is obliged to coordinate with the Cirebon City Government, namely:

a. Arranging designs and implementing TJSL activities following the principles of good corporate governance by observing the Cirebon City Government's policies and applicable laws and regulations.

b. Delivering the plan, implementation, and evaluation of TJSL from each company to the Cirebon City Government.

c. Coordinating before implementing TJSL in written form to the Cirebon City Government.

d. Grow, Strengthen and develop a network system of cooperation and partnerships with other parties and carry out studies, monitoring, and evaluation of the implementation of TJSL by taking into account the interests of the company, city government, the community, and environmental sustainability.

Meanwhile, the TJSL Perwali also stipulates the obligation to coordinate in the CSR Program, namely:

1. The Facilitation Team has the main task of assisting the Mayor in coordinating the planning, implementation, guidance, and supervision of the TJSL program in the regions.

2. To carry out its main tasks, the Facilitation Team has the following functions:

a. Preparation of the Facilitation Team work plan.

b. Coordinating the TJSL program planning.

c. Coordinating the implementation of the TJSL program.

d. Coaching and supervising the planning and implementation of the TJSL program.

e. Reporting and evaluation of the TJSL program.

3. TJSL partners in implementing programs and activities must coordinate and report the Program, and Activity Plans to the TJSL Facilitation Team.

Based on the description above, companies must coordinate with the Cirebon

City Government in poverty reduction through the CSR Program. However, most companies ignore their obligation to coordinate but directly implement CSR 
programs to target groups. This causes CSR programs to be often not on target, overlapping, and not following the Cirebon City Government's agenda.

To date, out of 170 companies in Cirebon City, only $28(16.5 \%)$ coordinate with the Cirebon City Government in the CSR Program, namely:

1. Representative Office of Bank Indonesia Cirebon, in activities:

a. Establishment of BI Corner at SMAN 2 Kota (2015) and in Unswagati (2018).

b. Construction of a Temporary Final Disposal Site (TPSS) in the Bima City Stadium area (2016).

c. Coaching and training for UMKM (every year).

2. Bank bjb Kota Cirebon, in activities:

a. Assistance for religious facilities for 30 mosques (2017).

b. Renovation of 3 elementary classrooms (2018).

c. The assistance of 1 unit of the ambulance for Gunung Jati Regional Hospital (2018).

d. Funding assistance for the Kasepuhan Palace (2018).

e. Social assistance (annually).

3. PT. Telkomsel, in the Loop Arena construction in the Bima Stadium, Cirebon City (2018).

4. PT. Cinta Damai Putra Bahagia, assisting 1 unit of garbage collection car (2018).

5. As many as 7 Regional Companies are members of the Cirebon City Regional Company Forum, in the construction of a road median park on Jan. Cipto Mangunkusumo Cirebon (2019).

6. PT. Kereta Api Indonesia DAOP III Cirebon, assisting 1 unit of garbage collection car (2019).

7. As many as 16 companies that are members of the TJSL Forum are carrying out road island construction activities in 16 points spread across Cirebon City (2020).

If we look closely, the CSR program activities carried out by the company in coordination are mostly not related to poverty reduction. This is because the Cirebon City Government does not prioritize CSR programs for poverty reduction but other programs such as facilities and infrastructure and cleanliness. Green Open Space (RTH), the arrangement of squares, parks, roads, and sidewalks. Whereas in Perwali Number 42 of 2015, it is emphasized that the TJSL Program is one of the poverty reduction programs.

In the context of poverty alleviation through the CSR program, the company has provided various social assistance in the form of compensation (goods, money, groceries), scholarships, mass circumcision, free medical treatment, revolving fund loans, training, and guidance for MSMEs, and others. However, most companies provide social assistance and programs directly to target groups without coordinating with the Cirebon City Government. Thus, the company's participation 
in coordinating with the Cirebon City Government in poverty reduction through the CSR Program is meager.

According to Tjokroamidjojo (1993), three factors influence participation: leadership, communication, and education. Leadership is essential in encouraging company participation to coordinate with the Cirebon City Government in the CSR Program because it is the leader who will drive the company's participation. The leadership in question is primarily the mayor of Cirebon's leadership as a coordinator, facilitator, innovator, locomotive, and main driving force in the CSR Program in Cirebon City. This leader's existence is one of the principles of coordination (Sugandha, 1991), namely the existence of a coordinator who can lead and mobilize and monitor this cooperation and lead joint problem-solving problems.

The mayor of Cirebon must do and have as a leader in the CSR Program are making regulations, having a vision and mission, having the commitment, having innovation and creativity, forming organizations, setting and implementing rewards and punishments, and being able to embrace company leaders.

According to Galbraith (Stoner, 1986), rules or rules are one of the basic management technique approaches to achieve effective coordination. In this case, CSR regulations have a significant role in achieving effective coordination because these regulations govern the CSR program's coordination mechanism. Besides, regulations are the legal basis for legality to implement CSR programs.

Cirebon City Government already has two regulations governing CSR: Perda TJSL (Perda No. 14 of 2012) and Perwali TJSL (Perwali No. 38 of 2016). In the Perda and Perwali, coordination mechanisms are regulated in the CSR Program. Besides, coordination in poverty reduction is also regulated in Perwali Number 42 of 2015 concerning Coordination and Poverty Alleviation Mechanisms in Cirebon City. In Perwali, it is emphasized that the CSR program is one of the poverty reduction programs in the city of Cirebon whose implementation must be carried out in a coordinated manner.

Based on the description above, the Mayor of Cirebon as a leader has made regulations on CSR in the form of the TJSL Regional Regulation and Perwali. However, the stipulation of the TJSL Perda and Perwali was four years apart, where the TJSL Perda was enacted on December 17, 2012, while the TJSL Perwali was enacted on December 13, 2016. The stipulation of the TJSL Perwali and Perwali four years ago resulted in the TJSL Perda not being implemented effectively because there was no TJSL Perwali as its implementing regulations. The main cause of the delay in determining the TJSL Perwali was the tug of interest between the Cirebon City Government and the company leadership as the main target group of the Perda and Perwali TJSL.

Besides, when it was formulated in 2012, the TJSL Perda was rejected by company leaders who are members of the Cirebon City Indonesian Employers Association (Apindo) because the drafting of the Perda did not involve Apindo. The TJSL Perda is also considered to be detrimental to the company. Ando believes that the TJSL Perda does not need to be made because there are already laws and 
government regulations governing TJSL, namely Law Number 40 of 2007 concerning Limited Liability Companies and Government Regulation Number 47 of 2012 regarding TJSL Limited Liability Company.

According to Apindo Kota Cirebon, there is actually no problem with the existence or absence of TJSL Regional Regulations and Perwali because several companies in Cirebon City are members of Apindo implementing CSR programs since 2011 before the TJSL Perda and Perwali were born. These companies carry out CSR independently or through the Ciayumajakuning TJSL Forum, formed in 2010 based on the Decree of the Governor of West Java.

Now, entrepreneurs who are Apindo Kota Cirebon members can accept the TJSL Perda, but they accept it half-heartedly. This impacts the obedience and participation of company leaders to coordinate with the Cirebon City Government in the CSR Program. This is evident from the majority of companies distributing social assistance in the CSR Program directly to the target group without coordinating with the Cirebon City Government, even though according to Sugandha (1991), one of the principles of coordination is the obedience or loyalty of each party to their respective parts of the task and a predetermined schedule.

Besides, the Mayor of Cirebon, as a leader, is required to have a vision for the future (visionary). In this regard, in the 2013 Cirebon City Pilkada, the pair Ano Sutrisno-Nasrudin Azis won. However, on 19 February 2015, Mayor Ano Sutrisno died and was later replaced by his deputy (Nasrudin Azis). When he was running for Mayor and The Deputy Mayor for the 2013-2018 period, the pair Ano SutrisnoNasrudin Azis had a vision that was later poured into the 2013-2018 vision of Cirebon City. This vision has also been outlined in the Cirebon City Medium-Term Development Plan (RPJMD) 2013-2018, namely: "The realization of Cirebon City as a Religious, Safe, Advanced, Aspirational and Green (FRIENDLY) City in 2018".

The CSR program is one of the programs to realize the "Advanced" vision, which means that Cirebon City is a city that is developing in a better direction in various fields of life and has high competitiveness compared to the progress of other cities in the regional and national regions. While the mission that is relevant to the CSR Program is "Increasing community participation in development." The participation here includes the participation of companies and other stakeholders in the CSR Program in Cirebon City.

The commitment of the Mayor of Cirebon in the CSR Program can be seen from the stipulation of the TJSL Regional Regulation (2012), the establishment of a TJSL Perwali (2016), the formation of the TJSL Facilitation Team (2017), holding a forum "Synergy of TJSL City of Cirebon" (2017), holding a forum "Gala Dinner and Formation Cirebon City TJSL Forum "(2018), and the establishment of the TJSL Forum. The majority of company leaders themselves consider the Mayor's commitment to be weak. Based on research, it is known that the Mayor's weak commitment is evident from the results of the joint meeting in the form of the "Cirebon City TJSL Synergy" forum (30 November 2017), which is not immediately followed up. One of them is the establishment of the City TJSL Forum. Cirebon, 
which was only formed a year later (26 December 2018). The formation of the TJSL Forum itself turned out not to be a pure initiative of the Mayor but because there was an instruction from West Java Governor Ridwan Kamil on 22 November 2018. Local governments throughout West Java form the TJSL Forum in their respective regions. To realize regional superior programs without relying on the APBD.

The CSR program also requires a high touch of innovation and creativity from the Mayor of Cirebon. However, based on research, Nasrudin Azis, as the Mayor of Cirebon, is very minimal in innovation and creativity in managing Cirebon City. It can be said that there have been no significant breakthroughs made by the Mayor while leading the city of Cirebon since 2015, including innovation and creativity in the CSR Program.

This is much different from the city of Bandung, which both have the TJSL Perda since 2012. For example, the Bandung City Government under Ridwan Kamil's leadership in 2016 received TJSL funds from 194 companies amounting to Rp. 32 billion. The funds have been channeled into 180 physical and non-physical development programs through the Bandung City TJSL Forum. One of the programs that have become an example of effective collaboration in the TJSL Program in Bandung is constructing the Ujung Berung square. This square is now the belle of family recreation in the East Bandung area. The plaza was built from the company's TJSL fund; the square's design was made by residents under the mayor's supervision, while each village carries out the management in turn (www.pikiranrakyat.com). In addition to the construction of the Ujung Bering square, the TJSL funds in Bandung City are also used to arrange city parks, the procurement of the Bandros tour bus (Bandung Tours on Bus), and other programs that are very beneficial to the community and regional development.

After being elected as the Governor of West Java, Ridwan Kamil instructed his innovation and creativity to be followed by districts/cities in West Java, including in the CSR Program, by forming the TJSL Forum in each district/city. The city of Cirebon itself has received the assistance of five bus units from the Provincial Government called Citrus (Cirebon Tours on Bus), such as Bandros in Bandung City. Besides, the plaza, sidewalks, and main streets in Cirebon City are currently being styled to be as beautiful as in the City of Bandung at the expense of the West Java Province APBD.

To support the CSR Program in Cirebon City, the Mayor of Cirebon has formed two independent organizations to coordinate on the CSR Program, namely the TJSL Facilitation Team (2017) and the TJSL Forum (2019). The TJSL Facilitation Team has SKPD officials associated with the CSR Program, while the TJSL Forum consists of company leaders. The TJSL Facilitation Team was formed in 2017 based on the Decree of the Mayor of Cirebon Number 460.05 / Kep.75-ASS.EKBANG / 2017, while the TJSL Forum was formed in 2019 based on the Decree of the Mayor of Cirebon Number 460.05 / Kep.121-Adm.Perek / 2019 According to Galbraith (Stoner, 1986), establishing an independent organization is one of the coordination approaches to reduce the need for coordination. 
The Cirebon City Development Planning Agency facilitated the CSR program in Cirebon City from 2013-2016. However, since 2017, the CSR Program's facilitation has been handed over to the TJSL Facilitation Team, which consists of related SKPD elements. While structurally, the work unit that spearheads the TJSL facilitation is the Regional Secretariat of Cirebon City's Economic Administration Section.

The TJSL Facilitation Team and the TJSL Forum are two organizations that carry different interests. The TJSL Facilitation Team carries the interests of the Cirebon City Government, while the TJSL Forum carries the company's interests. The two organizations coordinate the CSR Program. However, the formation of the two organizations is two years apart, so that during these two years, the coordination between the two organizations was not yet able to run.

Before the TJSL Forum was formed, coordination was carried out directly between the Cirebon City Government c.q. The TJSL Facilitation Team and company leaders informal joint meeting forums. After the TJSL Facilitation Team and the TJSL Forum were formed, coordination and communication between the two organizations were constrained by sectoral egos between organizations due to differences in orientation of interests and goals between them, which led to the difficulty of reaching a mutual agreement. Following Stoner's (1986) opinion, differences in orientation between organizations are a major obstacle to coordination. Meanwhile, according to Sugandha (1991), the collective agreement is an important principle that must be realized in coordination.

One of the Cirebon City TJSL Forum activities is to sign an agreement or Memorandum of Understanding (MoU) with the Cirebon City Government to build road island parks in 18 points spread across Cirebon City. The MoU's signing was carried out on December 18, 2019, to realize the target of park management in 2020, whose budget comes from CSR funds from 16 companies in Cirebon City that are members of the TJSL Forum. The road island park's construction is currently still ongoing and will be completed at the end of the 2020 fiscal year. This activity is clear evidence of the company's participation in the CSR Program.

Rewards and punishments are essential in encouraging company leaders to implement the CSR program, including its obligation to coordinate with the Cirebon City Government in the CSR Program. Rewards and punishments have been stipulated in the TJSL Regional Regulation, namely that the Cirebon City Government rewards companies that have implemented TJSL. It is also stipulated that the form of awards, procedures for assessing, nominating, and determining companies entitled to receive awards are further stipulated in Perwali TJSL. However, the TJSL Perwali does not regulate the award. Besides, the TJSL Perda only states that the Cirebon City Government applies sanctions to the person in charge of a business and/or activity if a violation is found following the prevailing laws and regulations. The TJSL Perda does not explain the form of the sanctions. In the TJSL Perwali, there is also no provision regarding these sanctions.

The implementation of rewards and punishments in the CSR Program has also not been implemented due to weak law enforcement of the TJSL Perda and 
Perwali. This has resulted in most companies implementing CSR programs directly to target groups without coordinating with the Cirebon City Government, including programs in poverty alleviation.

While the company leadership itself considers the award necessary, sanctions are unnecessary because CSR is only a responsibility, not a company obligation. According to the author, in this case, the company leadership forgets one important thing, namely the form of corporate responsibility in fact not only philanthropic responsibility (generosity) in the form of concern for the environment and society but also legal responsibility, namely having to comply with the applicable laws and regulations, including the Perda and Perwali TJSL.

One of the important roles of the leader (this is the Mayor of Carbon) in the CSR Program is embracing company leaders to coordinate and collaborate with the Cirebon City Government in the CSR Program. However, the Mayor of Cirebon is less able to embrace company leaders to coordinate and collaborate with the City Government Cirebon in the CSR Program. This causes most companies to implement CSR programs directly to target groups without coordinating with the Cirebon City Government.

The mayor's lack of ability to embrace the company's leadership is related to his personal abilities as a leader. Besides, there is a feeling of shame if you have to beg company leaders to disburse CSR funds. Another cause is the mayor who does not respond to innovative and creative initiatives from the company, for example, the proposal of three BUMN leaders in 2017 to build old city tourism as previously explained, which causes the leaders of the three BUMNs to give up on establishing coordination and collaboration with the Cirebon City Government. In the CSR Program.

In addition to the leadership factor, the second factor is communication. Communication in the form of vertical information systems and lateral relationships is an approach to increasing coordination potential (Galbraith in Stoner, 1986). Communication is critical in supporting participation and coordination. With communication ineffective socialization, the parties will understand the activity to encourage them to participate in these activities. Effective communication is a prerequisite for effective coordination because coordination is the result of communication. The principles of coordination 1, 2, 4, and 6, according to Sugandha (1991), which have been previously described, are related to communication factors.

Communication in the CSR program includes information systems, formal communication, informal communication, and the frequency and strength of interactions. All of them need to be built and developed in the CSR Program, described below.

\section{a. Information System}

The CSR program is coordinative and collaborative because its implementation involves the Cirebon City Government (as the regulator and facilitator of the CSR Program) with companies (CSR program implementers) and other stakeholders. Therefore, between the Cirebon City Government and 
companies, and other stakeholders, it is necessary to build a network in an information system. Even so, until now, there is no such information system network. Besides, Cirebon City Government c.q. The TJSL Facilitation Team also does not have a database on the number and names of companies implementing the CSR program, the program's activities, and so on. This is because most companies implement CSR programs directly to target groups without reporting to and coordinating with the Cirebon City Government.

To create a CSR program network, the Cirebon City TJSL Facilitation Team in 2019 plans to build a CSR website as a medium of communication and information between the Cirebon City Government c.q. TJSL Facilitation Team with company leaders in the CSR Program. However, until now, the CSR website's construction has not been realized even though the website is essential as a medium of information, communication, and coordination between the Cirebon City Government and companies in the CSR Program.

\section{b. Formal Communication}

Formal communication between the Cirebon City Government and company leaders is carried out through informal joint meeting forums. So far, formal communication has been carried out in two forums, namely the "Cirebon City TJSL Synergy" forum (2017) and the "Cirebon City TJSL Forum Formation" forum (2018).

The first forum was the "Cirebon City TJSL Synergy" forum, held on November 30, 2017. In that forum, the Cirebon City Government invited 92 company leaders, but only 36 people (39\%) attended. Meanwhile, the second forum was the "Gala Dinner forum. and the formation of the Cirebon City TJSL Forum "held on December 26, 2018. In that forum, the Cirebon City Government invited 100 company leaders, but only 56 people attended. Thus the participation of company leaders in the two joint meeting forums formally is not optimal.

Besides, some company elements who attended the forum were not company leaders but were represented by subordinate officials who did not have the authority to make decisions. This caused important decisions not to be decided at the time the forum was held. Another weakness in the forum was the Government. The city of Cirebon does not follow up on joint decisions that resulted from the forum in informal forums.

After the Cirebon City TJSL Forum was formed in 2019, formal communication between the Cirebon City Government and the company was carried out by the TJSL Facilitation Team (representative of the Cirebon City Government) and the TJSL Forum (representation of company leaders). However, during 2019-2020 there were only two formal meetings conducted between the two organizations.

\section{c. Informal Communication}

Besides formal communication, informal communication also plays an important role in establishing coordination between the Cirebon City Government and companies in the CSR Program. This informal communication includes lobbying with a persuasive approach from the Cirebon City Government c.q. TJSL Facilitation 
Team to company leaders c.q. TJSL Forum. However, these informal meetings are rarely held, even though these informal meetings are essential to follow up on formal meetings held previously.

During the informal meeting, the Cirebon City Government c.q. The TJSL Facilitation Team can lobby and persuasive approaches to company leaders. Company leaders' commitment built in previous formal communications can be maintained and continue incoordination or even collaboration. However, because these informal meetings are rarely held, the company's commitments built before informal meetings have not continued. One of the reasons is the Cirebon City Government c.q. The TJSL Facilitation Team feels embarrassed if they beg for companies to coordinate and collaborate in the CSR Program.

\section{d. Frequency and Strength of Interactions}

The frequency and strength of interaction are fundamental in coordination. The more frequent the interaction frequency, the higher the interaction between the coordinating parties (in this case, the Cirebon City Government and company leaders). However, as previously described, the frequency of formal interactions between the Cirebon City Government c.q. TSL Facilitation Team with companies c.q. The TJSL forum is still minimal. Meanwhile, the frequency of informal interactions is infrequent.

In this case, Cirebon City Government c.q. The TJSL Facilitation Team only hopes that company leaders have a high awareness of coordinating with the Cirebon City Government in implementing the CSR Program because this coordination has become the company's obligation following the TJSL Regional Regulation. However, hoping for awareness is not enough. Cirebon City Government c.q. The TJSL Facilitation Team must be proactive in conducting formal and informal communication to raise awareness of company leaders to coordinate and collaborate with the Cirebon City Government in the CSR / TJSL Program.

Apart from leadership and communication, the education factor also plays a significant role in encouraging company participation in the CSR Program in Cirebon City. In this case, the higher the education of company leaders, the higher their knowledge, understanding, and awareness, so that they will coordinate with the Cirebon City Government in the CSR Program. Education includes the level of education, awareness, knowledge, and understanding of company leaders.

The level of education of company leaders is generally quite high: at least a high school education; many have even bachelor's and master's degrees. However, a high level of education alone is not enough to encourage company leaders to coordinate with the Cirebon City Government in the CSR program. Apart from the level of education, there are several other factors related to education, namely the awareness, knowledge, and understanding of company leaders of the CSR program's coordination mechanism as regulated in the Perda and Perwali TJSL.

The awareness of company leaders is essential to encourage them to coordinate with the Cirebon City Government in the CSR Program. However, the awareness of this company's leadership does not come automatically but must 
continue to be built by the Cirebon City Government through formal and informal communication. In the previous description, it has been explained that formal communication and informal activities are still not optimal, which causes the interaction between the Cirebon City Government and company leaders in the CSR Program to be less strong. This causes a lack of awareness of company leaders to implement CSR programs to coordinate and collaborate with the Cirebon City Government. This can be seen from most companies that ignore the obligation to coordinate following the provisions of the TJSL Regional Regulation.

The company's leadership knowledge of the coordination mechanism in the CSR program is a significant factor. In this case, company leaders must know the CSR program's coordination mechanism as regulated in the Perda and Perwali TJSL. Based on research results, many company leaders do not know the program CSR's coordination mechanism, even though the coordination mechanism has been clearly regulated in the Perda and Perwali TJSL.

This fact shows the lack of socialization regarding the TJSL Perda and Perwali to company leaders. Based on the research, it is known that the Perda and Perwali TJSL have been socialized by distributing the Perda and Perwali to company leaders in the city of Cirebon. The TJSL Perda and Perwali have also been uploaded to the Cirebon City Legal Documentation and Information Network (JDIH) website. In this case, the Cirebon City Government has the principle that if a statutory regulation has been uploaded in the JDIH, the parties concerned are considered to have known the regulations. According to the author, this opinion simplifies the problem because many company leaders do not yet know the coordination mechanism in the CSR Program as regulated in the Perda and TJSL Perwali.

In the previous description, it has been explained that many company leaders do not yet know the coordination mechanism in the CSR program, which is regulated in the TJSL Perda and Perwali. This causes not all company leaders to understand the TJSL Perda and Perwali. This will affect company leaders' participation to coordinate with the Cirebon City Government in the CSR Program. On the other hand, company leaders who already know and understand the CSR Program's coordination mechanism also do not guarantee them to coordinate with the Cirebon City Government in the CSR Program. This is evident from most companies implementing CSR programs directly to target groups without coordinating with the Cirebon City Government.

\section{E. CONCLUSION}

The company's participation in coordinating with the Cirebon City Government in poverty reduction through the Corporate Social Responsibility (CSR) Program has not been optimal because most companies carry out CSR programs directly to target groups without coordinating with the City Government. This can be seen from 170 companies in Cirebon City; only 22 companies coordinate with the Cirebon City Government in CSR Programs. Most of the CSR programs are not related to poverty reduction. 
The factors that affect the company's participation in coordinating with the Cirebon City Government in poverty reduction through the CSR program are the Cirebon mayor's leaders, less optimal communication, and the low level of education of company leaders so that the awareness to coordinate is still lacking. The mayor of Cirebon's leadership has not been optimal in making regulations, vision and mission, commitment, innovation, and creativity, forming organizations, establishing and implementing rewards and punishments, and embracing company leaders. Communication is not yet optimal in terms of information systems and formal communication and informal communication between Cirebon City Government with company leaders. Education of company leaders is still low in terms of awareness to coordinate with the Cirebon City Government and knowledge and understanding of the coordination mechanism in the CSR Program regulated in the Perda and Perwali TJSL due to lack of communication in the form of socialization.

\section{REFERENCES}

1. Anatan, L. (2009). Coorporate Social Responsibility (CSR): Tinjauan Teoritis Dan Praktik Di Indonesia. Jurnal Manajemen Maranatha, 8(2), 66-77.

2. Anita, A., \& Yulianto, A. (2016). Pengaruh Kepemilikan Manajerial Dan Kebijakan Dividen Terhadap Nilai Perusahaan. Management Analysis Journal, 5(1).

3. Aras, G.\& Crowther, D. (2007). Sustainable Corporate Social Responsibility And The Value Chain. Dalam David Crowther And M. M. Zain (Eds.). New Perspectives On Corporate Social Responsibility. Sage Publication, Inc

4. Ardimas, W., \& Wardoyo, W. (2015). Pengaruh Kinerja Keuangan Dan Corporate Social Responsibility Terhadap Nilai Perusahaan Pada Bank Go Public Yang Terdaftar Di BEI. Benefit: Jurnal Manajemen Dan Bisnis, 18(1), 57-66.

5. Carroll, A.B. (1991). The Pyramid Of Corporate Social Responsibility: Toward The Moral Management Of Organizational Stakeholders. Business Horizons, 34(4).

6. Creswell, J.W. (2014). Research Design. Pendekatan Kualitatif, Kuantitatif, Dan Mixed. Yogyakarta: Pustaka Pelajar.

7. Daniels, P. W., \& Bryson, J. R. (2002). Manufacturing Services And Servicing Manufacturing: Knowledge-Based Cities And Changing Forms Of Production. Urban Studies, 39(5-6), 977-991.

8. Endarmoko, E. (2006). Tesaurus Bahasa Indonesia. Jakarta: Gramedia Pustaka Utama

9. Handayaningrat, S.(2000). Pengantar Studi Ilmu Administrasi Dan Manajemen. Jakarta: Haji Masagung.

10. Kamil, A., \& Herusetya, A. (2012). Pengaruh Karakteristik Perusahaan Terhadap Luas Pengungkapan Kegiatan Corporate Social Responsibility. Media Riset Akuntansi, 2(1). 
11. Decree Of The Mayor Of Cirebon Number 460 Of 2017 Concerning The Establishment Of A TJSL Facilitation Team Within The Cirebon City Government.

12. Keputusan Walikota Cirebon Nomor 460 Tahun 2019 Tentang Pembentukan Forum Tanggung Jawab Sosial Dan Lingkungan Perusahaan Kota Cirebon.

13. Lindahl, M., Sundin, E., \& Sakao, T. (2014). Environmental And Economic Benefits Of Integrated Product Service Offerings Quantified With Real Business Cases. Journal Of Cleaner Production, 64, 288-296.

14. Moleong, L.J. (2009). Metode Penelitian Kualitatif. Bandung: PT. Remaja Rosdakarya

15. Nazir, M. (2011). Metode Penelitian. Jakarta: Gahlia Indonesia.

16. Nurbaety, A., Ratnasih, R., \& Ramdan, H. (2015). Analisis Implementasi Corporate Social Responsibility PT. Bio Farma Di Desa Sukamulya Kabupaten Sukabumi. Jurnal Sosioteknologi, 14(2), 141-154.

17. Oktariani, N. W., \& Mimba, N. P. S. H. (2014). Pengaruh Karakteristik Perusahaan Dan Tanggung Jawab Lingkungan Pada Pengungkapan Tanggung Jawab Sosial Perusahaan. E-Jurnal Akuntansi, 6(3), 402-418.

18. Cirebon City Regional Regulation Number 14 Of 2012 Concerning Corporate Social And Environmental Responsibility (TJSL) In Cirebon City.

19. The Republic Of Indonesia Government Regulation Number 47 Of 2012 Regarding Social And Environmental Responsibility Of Limited Liability Companies.

20. Regulation Of The Mayor Of Cirebon Number 38 Of 2016 Concerning Guidelines For The Implementation Of Regional Regulations Of The City Of Cirebon Number 14 Of 2012 Concerning Implementation Of Corporate Social And Environmental Responsibility (TJSL) In Cirebon City

21. Cirebon Mayor Regulation Number 42 Of 2015 Concerning Coordination And Poverty Alleviation Mechanisms In Cirebon City.

22. Putra, E. N., \& Rahardjo, S. N. (2011). Pengaruh Karakteristik Perusahaan Terhadap Pengungkapan Corporate Social Responsibility (CSR)(Doctoral Dissertation, Universitas Diponegoro).

23. Rusli, B. (2015). Isu-Isu Krusial Administrasi Publik Kontemporer. Bandung: Mega Rancage

24. Sastropoetro, R.A.S. (1990). Partisipasi, Komunikasi, Persuasi Dan Disiplin Dalam Pembangunan Nasional. Bandung: Alumni

25. Siagian, S.P. (2000). Administrasi Pembangunan. Konsep, Dimensi Dan Strateginya. Jakarta: Bumi Aksara

26. Stoner, J.A.F. \& Wankel, C. (1986). Management. New Jersey: Prentice Hall International, Inc

27. Subiantoro, O. H., \& Mildawati, T. (2015). Pengaruh Karakteristik Perusahaan Terhadap Pengungkapan Corporate Social Responsibility. Jurnal Ilmu Dan Riset Akuntansi (JIRA), 4(9). 
28. Sugandha, D. (1991). Koordinasi. Alat Pemersatu Gerak Administrasi. Jakarta: Intermedia

29. Suharto, E. (2013). Kemiskinan \& Perlindungan Sosial Di Indonesia. Bandung: Alfabeta

30. Tjokroamidjojo, B. (1993). Pengantar Administrasi Pembangunan. Jakarta: LP3ES

31. Tubagus, S. A. M. (2020). Pengaruh Ukuran Perusahaan, Struktur Modal, Dan Kepemilikan Institusional Terhadap Nilai Perusahaan. Jurnal Ilmu Dan Riset Manajemen (JIRM), 9(4).

32. Law Of The Republic Of Indonesia Number 40 Of 2007 Concerning Limited Liability Companies.

33. Westra, P., Sutarto \& Syamsi, I. (1990). Ensiklopedi Administrasi. Jakarta: CV. Haji Masagung

34. Wibisono, Y. (2007). Membedah Konsep Dan Aplikasi CSR(Corporate Social Responsibility). Jakarta: Gramedia Pustaka Utama.

35. Wijaya, M. (2012). Faktor-Faktor Yang Mempengaruhi Pengungkapan Tanggung Jawab Sosial Pada Perusahaan Manufaktur Yang Terdaftar Di Bursa Efek Indonesia. Jurnal Ilmiah Mahasiswa Akuntansi, 1(1), 26-30. 